\title{
Faktor-Faktor yang Mempengaruhi Nilai Perusahaan dengan Profitabilitas sebagai Variabel Intervening
}

\author{
Cahya Suryani ${ }^{1}$ \\ Fakultas Ekonomi dan Bisnis \\ Universitas Mataram, Indonesia \\ Email: cahyasuryani13@yahoo.com
}

\author{
Lilik Handajani ${ }^{2}$ \\ Fakultas Ekonomi dan Bisnis \\ Universitas Mataram, Indonesia
}

\author{
Lukman Effendy ${ }^{3}$ \\ Fakultas Ekonomi dan Bisnis \\ Universitas Mataram, Indonesia
}

\begin{abstract}
ABSTRAK
Penelitian ini bertujuan untuk menganalisis faktor-faktor yang mempengaruhi Nilai Perusahaan dengan menggunakan profitabilitas sebagai Variabel Intervening. Data penelitian diperoleh dari laporan keuangan tahunan perusahaan subsektor perbankkan yang terdaftar di Bursa Efek Indonesia tahun 2016 s/d 2018. Analisis data menggunakan teknik analisis jalur. Hasil analisis menunjukkan bahwa variabel intellectual capital yang di ukur dengan VAICTM tidak berpengaruh terhadap profitabilitas yang di proksikan dengan ROE dan nilai perusahaan yang di ukur menggunakan jumlah total aset, hal ini dikarenakan masih banyak perusahaan yang tidak memperhatikan intellectual capial pada perusahaannya, perusahaan lebih cendrung memperhatikan asset berwujud sedangkan Good corporate governance yang diproksikan dengan jumlah komite audit hanya berpengaruh signifikan pada nilai perusahaan sedangkan profitabilitas (ROE) berpengaruh signifikan terhadap Nilai perusahaan.
\end{abstract}

Kata Kunci: Nilai Perusahaan; Profitabilitas; Intellectual Capital; Good Corporate Governance.

\section{Factors Affecting The Value Of Companies With Profitability As Intervening Variables}

\section{ABSTRACT}

This study aims to analyze the factors that affect Company Value by using profitability as an Intervening Variable. The research data was obtained from the annual financial statements of the banking sub-sector companies listed on the Indonesia Stock Exchange in 2016 to 2018. Data analysis used path analysis techniques. The analysis shows that the intellectual capital variable measured by VAICTM has no effect on profitability that is proxied by ROE and the value of the company is measured using the total amount of assets, this is because there are still many companies that do not pay attention to intellectual capial on their companies, companies tend to pay more attention tangible assets while Good corporate governance which is proxied by the number of audit committees only has a significant effect on firm value while profitability (ROE) has a significant effect on firm value.

Keywords: Company Value; Profitability; Intellectual Capital; Good Corporate Governance.

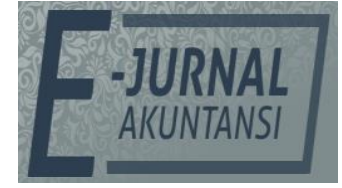

E-JA

e-Jurnal Akuntansi e-ISSN 2302-8556

Vol. 30 No. 7

Denpasar, Juli 2020

Hal.1857-1871

Artikel Masuk: 30 Mei 2020

Tanggal Diterima: 10 Juli 2020

The Article is Available in : https://ojs.unud.ac.id/index.php/Akuntansi/index 


\section{PENDAHULUAN}

Bersamaan dengan berkembangnya ilmu pengetahuan dan teknologi, proses bisnis juga berkembang dari bisnis yang didasarkan pada tenaga kerja (labor based business) menuju bisnis berdasarkan pengetahuan (knowledge based business), sehingga karakteristik utama perusahaan menjadi perusahaan berdasarkan pengetahuan (Sawarjuwono \& Kadir, 2003). Hal inilah yang menyebabkan perusahaan perbankan terus berupaya untuk melakukan pembenahan di segala sektor baik itu dalam penyempurnaan strategi bisnisnya maupun dalam masalah keuangan perusahaan. Tuntutan perkembangan teknologi juga mendorong setiap organisasi bisnis untuk dapat menciptakan efektivitas dan efisiensi dalam setiap aktivitas organisasinya guna pencapaian tujuan.

Tujuan jangka panjang perusahaan adalah mengoptimalkan nilai perusahaan, sehingga apabila suatu perusahaan dianggap memiliki nilai maka perusahaan itu berharga atau dalam artian memiliki prospek masa depan c). Nilai perusahaan merupakan persepsi investor terhadap perusahaan yang sering dikaitkan dengan asset yang dimiliki persahaan. Jumlah aset yang tinggi membuat nilai perusahaan juga tinggi. Tingginya nilai perusahaan dapat memberikan kemakmuran secara maksimum kepada pemilik perusahaan atau stakeholder. Ada beberapa factor yang mempengarhi peningkatan nilai perusahaan diantaranya adalah Intellectual Capital dan Corporate Governance.

Nilai perusahaan dari beberapa perusahaan dapat beberapa kali lipat lebih besar dari nilai buku aset perusahaannya. Adanya nilai tersembunyi yang tergambar dari persentasi nilai perusahaan diindikasikan bahwa perusahaan memiliki Intellectual Capital. Banyak perusahaan yang memiliki aktiva berwujud yang tidak signifikan dalam laporan keuangan namun penghargaan pasar atau nilai perusahaan tersebut sangat tinggi (Khanqah et al., 2012).

Teori sinyal menyatakan bahwa terdapat dorongan perusahaan untuk memberikan informasi laporan keuangan tahunan kepada pihak eksternal yang dapat menjadi sinyal bagi investor dan pihak potensial lainnya dalam mengambil keputusan ekonomi. Suatu pengungkapan dikatakan mengandung informasi apabila dapat memicu reaksi pasar, yaitu dapat berupa perubahan harga saham atau abnormal return. A pabila pengungkapan tersebut memberikan dampak positif berupa kenaikan harga saham, maka pengungkapan tersebut merupakan sinyal positif, begitupun sebaliknya (Wany, 2010).

Seorang manajer memiliki motivasi untuk mengungkapkan private information (informasi keuangan dan non-keuangan) secara sukarela karena perusahaan berharap informasi tersebut dapat diinterpretasikan sebagai sinyal positif mengenai kinerja perusahaan dan mampu mengurangi asimetri informasi. Pengungkapan Intellectual Capital dan Corporate Governance memungkinkan bagi investor dan stakeholder lainnya untuk lebih baik dalam menilai kemampuan perusahaan di masa depan, melakukan penilaian yang tepat terhadap perusahaan, dan mengurangi persepsi risiko (Rajannoor et al., 2014). Berdasarkan teori ini maka suatu pengungkapan laporan tahunan perusahaan merupakan informasi yang penting dan dapat mempengaruhi investor dalam proses pengambilan keputusan. Sedangkan berdasarkan pendekatan resource based theory dapat disimpulkan bahwa sumber daya yang dimiliki perusahaan berpengaruh terhadap kinerja perusahaan yang pada akhirnya akan 
meningkatkan nilai perusahaan (Lin, 2015). Menurut Ahriati et al., (2015) dan Earnest et al., (2013), agar dapat bersaing organisasi membutuhkan dua hal utama. Pertama, memiliki keunggulan dalam sumber daya yang dimilikinya, baik berupa aset yang berwujud (tangible assets) maupun yang tidak berwujud (intangible assets). Kedua, kemampuan dalam mengelola sumber daya yang dimiliki secara efektif dan efisien. Kombinasi yang apik dari keduanya akan menciptakan kompetensi yang khas dari sebuah perusahaan, sehingga mampu memiliki keunggulan kompetitif di banding para pesaingnya. Isu Intellectual Capital menjadi sangat penting dalam pengaruhnya terhadap peningkatan nilai perusahaan (Langeroodi et al., 2014). Selama ini pengungkapan intellectual capital sudah banyak dilakukan dalam menentukan value perusahaan. Selain memperbaiki pengungkapan laporan keuangan berupa pengungkapan intellectual capital, sebuah perusahaan juga perlu melakukan penerapan corporate governance yang baik. Corporate governance muncul karena dilatar belakangi beberapa permasalahan, antara lain adanya tuntutan akan transparansi dan independensi yang memicu perusahaan agar memiliki lebih banyak komisaris independen yang mengawasi tindakan-tindakan para eksekutif. Sehingga goal congruence diharapkan dapat terwujud guna mencapai tujuan perusahaan (Nida et al., 2015).

Peneitian terkait Intellectual Capital, Corporate Governance, nilai perusahaan dan profitabilitas di luar negeri maupun di Indonesia telah banyak dilakukan. Seyed Alireza Mosavi, (2012), Dženopoljac et al., (2016), Mojtahedi et al., (2013), (Bontis et al., 2015), Hashim et al., (2015), dan Farida et al., (2016) berhasil membuktikan Intellectual Capital berpengaruh positif terhadap nilai perusahaan. Namun demikian, hasil penelitian yang dilakukan Seyed Alireza Mosavi, (2012) dan (Bontis et al., 2015) berbeda dengan hasil penelitian yang dilakukan oleh Hanum et al., (2011) pada perusahaan Technology-Intensive di Malaysia. Hanum et al., (2011) mengungkapkan bahwa Intellectual Capital berpengaruh positif terhadap kinerja keuangan perusahaan tetapi tidak terdapat hubungan antara Intellectual Capital dengan nilai perusahaan. Widigdo (2013) berhasil menunjukkan bahwa Intellectual Capital berpengaruh positif terhadap kinerja keuangan perusahaan namun untuk Corporate Governance masih tidak terbukti dapat meningkatkan kinerja keuangan perusahaan pada perusahaan perbankan yang terdaftar di Bursa Efek Indonesia periode pengamatan 2009-2011 Berbeda dengan penelitian yang dilakukan widigdo (2013), Rajannoor et al., (2014) mengemukakan bahwa perusahaan dengan governance yang baik akan memiliki kinerja keuangan yang lebih efisien. Sejalan dengan penelitian yang dilakukan Diarto et al., (2016) yang berhasil menemukan adanya hubungan positif antara Corporate Governance dengan Kinerja keuangan Perusahaan yang diukur dengan ROA. Berbeda dengan penelitian yang dilakukan Nida (2015), dan (Fatimah et al., 2017), menganalisis Good corporate governance yang diproksikan kepemilikan manajerial, hasil penelitian menunjukkan kinerja keuangan tidak mampu memediasi hubungan antara good corporate governance dengan nilai perusahaan. Penelitian yang dilakukan Hadiwijaya et al., (2013), membuktikan bahwa Kinerja keuangan (ROA) sebagai variabel moderator mampu menunjukkan pengaruh yang signifikan terhadap hubungan antara intellectual capital (VAICTM) dan nilai perusahaan (PBV). Sedangkan penelitian yang dilakukan Jayanti \& Binastuti, 
(2017) membuktikan bahwa Return on Assets (ROA) hanya memediasi pengaruh Structural Capital Value Added (STVA) terhadap Tobin's Q pada perusahaan perbankan yang terdaftar di Bursa Efek Indonesia. Namun Return on Assets (ROA) tidak memediasi pengaruh Value Added Capital Employed (VACA) dan Value Added Human Capital (VAHU) terhadap Tobin's Q. Penelitian yang dilakukan oleh Sunarsih \& Mendra, (2012) dan Sudibya \& Restuti, (2014) membuktikan bahwa kinerja keuangan dapat memediasi hubungan antara modal intelektual dengan nilai pasar perusahaan.

Merujuk pada hasil penelitian sebelumnya yang tidak konsisten, penelitian ini ingin menguji kembali pengaruh Intellectual Capital dan Corporate Governance terhadap nilai perusahaan dan profitabilitas sebagai variable intervening dengan menggunakan beberapa pembaharuan diantaranya alat analisis dan tahun pengamatan serta indikator yg berbeda.

Penggunaan sumber daya yang effisien dapat memperkecil biaya sehingga akan mengakibatkan peningkatan laba perusahaan. Perusahaan yang menggunakan modal intelektualnya dalam suatu produksi tidak dapat meningkatkan biaya produksi di masa depan tetapi dapat mengurangi biaya produksi di masa depan sehingga dapat meningkatkan laba perusahaan Sudibya \& Restuti, (2014). Penelitian Bontis et al., (2015) menunjukkan bahwa intellectual capital berpengaruh positif dan signifikan terhadap nilai perusahaan. Penelitian yang sama oleh Farida et al., (2016) juga menunjukkan hasil yang sama yakni terdapat pengaruh positif dan signifikan antara modal intelektual dan nilai perusahaan. Berdasarkan konsep teori tersebut maka dapat diajukan hipotesis sebagai berikut :

$\mathrm{H}_{1}$ : Intellectual Capital berpengaruh secara signifikan terhadap Nilai Perusahaan.

Fama dan French (1998) dalam Wahyudi (2016) menungkapkan bahwa nilai perusahaan adalah harga jual perusahaan yang tercermin dari harga pasar sahamnya. Sedangkan tujuan jangka panjang perusahaan adalah memaksimalkan nilai perusahaan. Sehingga apabila suatu perusahaan menerapkan tata kelola perusahaan yang baik maka dianggap memiliki nilai maka perusahaan itu berharga atau dalam artian memiliki prospek masa depan. Hasil penelitian Widigdo (2013), Rajannoor et al., (2014) yang menguji pengaruh Good Corporate Governance menunjukkan bahwa kepemilikan manajerial simultan berpengaruh positif dan signifikan terhadap nilai perusahaan. Berdasarkan konsep teori tersebut maka dapat diajukan hipotesis sebagai berikut :

$\mathrm{H}_{2}$ : Good Corporate Governance berpengaruh secara signifikan terhadap Nilai Perusahaan.

Kinerja keuangan menurut Desi (2014) berorientasi jangka pendek yaitu untuk mencari keuntungan atau profit. Ukuran dari jangka pendek adalah sekitar satu tahun siklus hidup perusahaan. Sedangkan nilai perusahaan merupakan nilai atas surat berharga hutang dan ekuitas perusahaan yang beredar yang merupakan tujuan jangka panjang perusahaan. Dari pemaparan diatas maka dapat disimpulkan apabila kinerja perusahaan yang merupakan tujuan jangka pendek perusahaan meningkat maka nilai atas surat berharga perusahaan yang beredar yang merupakan tujuan jangka perusahaan akan meningkat. Maka dari itu kinerja perusahaan dirasa dapat meningkatkan nilai perusahaan (Desi, 2014) Hal ini sesuai denhan penelitian Ogolmagai (2013) yang 
menunjukkan hasil bahwa kinerja keuangan berpengaruh positif dan signifikan terhadap nilai perusahaan. Didukung oleh penelitian Telepta (2011) yang menunjukkan hasil yang sama bahwa ada pengaruh positif dan signifikan antara kinerja keuangan perusahaan dan nilai perusahaan. Berdasarkan konsep teori tersebut maka dapat diajukan hipotesis sebagai berikut :

$\mathrm{H}_{3}$ : Kinerja Perusahaan berpengaruh secara signifikan terhadap Nilai Perusahaan.

Modal intelektual yang baik dapat mengelola keuangan perusahaan yang baik dengan pengetahuan dan teknologi yang dimilikinya, sehingga kinerja keuangan perusahaan akan semakin meningkat. Apabila kinerja keuangan perusahaan semakin meningkat maka minat pemegang saham dalam menginvestasikan assetnya terhadap perusahaan akan meningkat. Hal ini memicu nilai perusahaan yang terus meningkat. Maka dari itu kinerja keuangan perusahaan dirasa mampu memediasi hubungan antara modal intelektual perusahaan dengan nilai perusahaan. Penelitian Sunarsih \& Mendra, (2012) dan Sudibya \& Restuti, (2014) menunjukkan bahwa modal intellektual berpengaruh positif terhadap nilai perusahaan dan kinerja perusahaan dapat memediasi hubungan antara modal intelektual dengan nilai perusahaan. Berdasarkan teori diatas maka dapat ditarik hipotesis sebagai berikut:

$\mathrm{H}_{4}$ : Kinerja keuangan perusahaan dapat memediasi hubungan antara intellectual capital dengan nilai perusahaan.

Tata kelola perusahaan yang baik dalam melakukan sumber daya organisasi yang baik dapat meningkatkan keuntungan jangka pendek perusahaan dalam menghasilkan laba bagi perusahaan. Sehingga Kinerja keuangan perusahaan akan meningkat seiring dengan meningkatnya tata kelola perusahaan yang baik. Semakin meningkatnya posisi keuangan perusahaan maka nilai perusahaan akan semakin baik dimata investor. Maka dari itu kinerja keuangan perusahaan dirasa mampu memodiasi hubungan antara tata kelola perusahaan dengan nilai perusahaan. Penelitian Dianawati \& Fuadati, (2016) mengungkapkan bahwa Kinerja keuangan perusahaan dapat memediasi hubungan antara tata kelola perusahaan yang baik terhadap nilai perusahaan. Berdasarkan teori diatas maka dapat ditarik hipotesis sebagai berikut:

$\mathrm{H}_{5}$ : Kinerja keuangan dapat memediasi hubungan antara good corporate governance dengan nilai perusahaan.

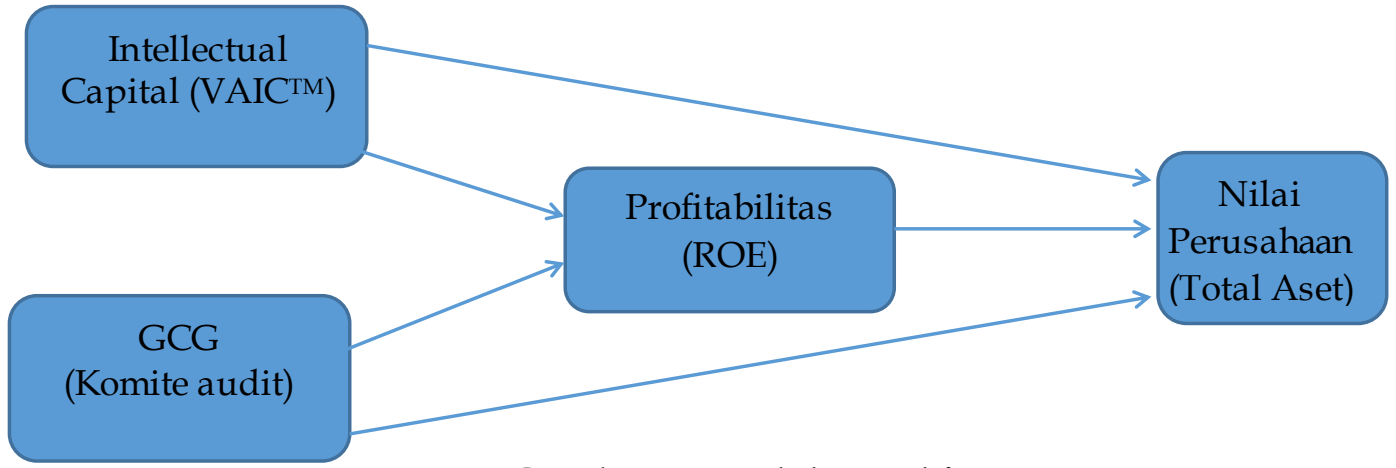

Sumber: Data Penelitian, 2019

Gambar 1. Model Peneltian 


\section{METODE PENELITIAN}

Populasi penelitian ini adalah perusahaan subsektor perbankan yang terdaftar di Bursa Efek Indonesia (BEI) selama periode 2016-2018. Pengambilan sampel dilakukan melalui teknik purposive sampling. Jumlah sampel penelitian yang menenuhi kriteria adalah sebanyak 34 perusahaan.

Penelitian ini menggunakan data kuantitatif berupa angka-angka keuangan perusahaan. Sumber data yang digunakan berupa data sekunder yang diperoleh dari website BEI www.idx.co.id. Adapun variabel independen penelitian adalah intellectual capital dan good corporate governance. Variabel independen yang digunakan adalah nilai perusahaan. Sedangkan variabel mediasi adalah kinerja keuangan.

Intellectual capital menggunakan proksi VAICTM yang dikembangkan oleh Pulic. Komponen utama dari VAIC yang dikembangkan Pulic (1999) tersebut dapat dilihat dari sumber daya perusahaan, yaitu physical capital (VACA Value Added CapitalEmployed), human capital (VAHU - Value Added Human Capital), dan structural capital (STVA - Structural Capital Value Added). Penelitian-penelitian Intellectual Capital dengan menggunakan metode VAICTM telah banyak dilakukan di dalam maupun di luar negeri. Pemakaian model VAICTM sebagai proksi atas IC mengacu pada penelitian (Seyed Alireza Mosavi, 2012),

Value Added Capital Employed (VACA) adalah rasio dari value added (VA) terhadap capital employed (CE). Pulic (2000) mengasumsikan bahwa jika 1 unit dari capital employed (CE) menghasilkan return yang lebih besar daripada perusahaan lainnya, itu berarti perusahaan tersebut lebih baik dalam menggunakan CE-nya. Value Added Capital Employed (VACA) merupakan kemampuan perusahaan dalam mengelola sumber daya berupa capital asset yang jika dikelola dengan baik dapat meningkatkan nilai perusahaan (Nuryaman, 2015) dan (Harryani et al., 2013). Rumus untuk menghitung VACA adalah sebagai berikut :

$V A C A=\frac{\text { VA }}{C E}$.

Keterangan:

$\mathrm{VA}=$ Value Added, yaitu total penjualan dan pendapatan lain dikurangi dengan beban dan biaya-biaya (selain beban karyawan).

$\mathrm{CE}=$ Capital Employed, yaitu dana yang tersedia atau dimiliki oleh perusahaan (total ekuitas).

VAHU adalah rasio dari value added (VA) terhadap human capital (HC). Value Added Human Capital (VAHU) menunjukkan berapa banyak VA dapat dihasilkan dengan dana yang dikeluarkan untuk tenaga kerja. Hashim et al., (2015) menjelaskan bahwa human capital adalah kemampuan karyawan untuk mengolah produk dengan baik sehingga dapat menjaring konsumen dan konsumen tidak akan beralih kepada pesaing dirumuskan sebagai berikut :

$V A H U=\frac{V A}{H C}$ 
Keterangan:

$\mathrm{VA}=$ Value Added, yaitu total penjualan dan pendapatan lain dikurangi dengan beban dan biaya-biaya (selain beban karyawan) VA dihitung sebagai selisih antara output dan input (Lisdayanti et al., 2016).

$\mathrm{HC}=$ Human Capital, yaitu beban karyawan atau tenaga kerja yang ditanggung oleh perusahaan (total gaji, upah dan pendapatan karyawan).

STVA adalah rasio structural capital (SC) terhadap value added (VA). Rasio ini mengasumsikan jumlah structural capital yang dibutuhkan untuk manghasilkan satu Rupiah dari value added Structural capital. Structural Capital Value Added (STVA) adalah kemampuan perusahaan dalam memenuhi proses produksi perusahaan dan strukturnya yang mendukung karyawannya untuk menghasilkan kinerja intelektual yang optimal serta kinerja bisnis secara keseluruhan, misalnya: sistem operasional perusahaan, proses manufacturing, budaya organisasi, filosofi manajemen dan semua bentuk intellectual property yang dimiliki dan dikuasai oleh perusahaan (Hanum et al., (2011).

$S T V A=\frac{S C}{V A}$

Keterangan:

$$
\begin{array}{ll}
\text { SC (structural capital) } & =\mathrm{VA}-\mathrm{HC} \\
\mathrm{VA} & =\text { Value Added }
\end{array}
$$

GCG diproksikan dengan ukuran komite audit perusahaan baik auditor internal maupun auditor independen. Nilai perusahaan diproksikan dengan nilai logaritma natural (ln) total asset perusahaan. Profitabilitas diproksikan dengan nilai return on equity (ROE), yang menggambarkan kemampuan perusahaan dalam menghasilkan laba berdasarkan total ekuaitas perusahaan.

Teknik analisis data menggunakan analisis jalur. Analisis jalur digunakan untuk mengetahui bobot dan signifikansi pengaruh variabel independen terhadap variabel dependen. Pengujian hipotesis dilakukan melalui uji t. Penelitian ini melibatkan variabel mediasi (intervening), karena itu pengujian signifikan efek mediasi menggunakan formulasi Sobel Test yang dikembangkan oleh Baron dan Kenny. Adapun model yang dikembangkan untuk penelitian ini adalah:

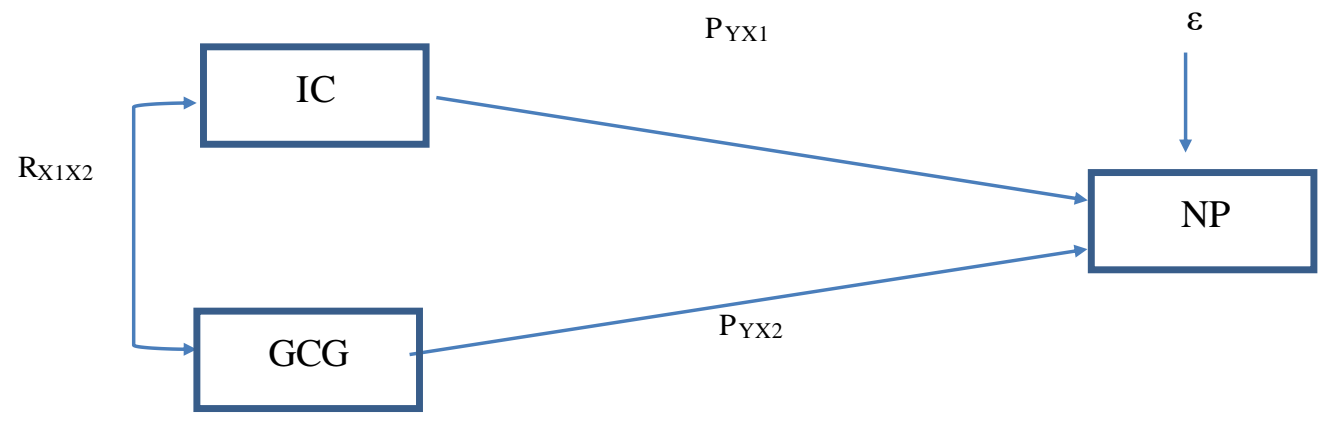

Gambar 2. Model Jalur Struktur 1

Sumber: Data Penelitian, 2019 
Variable IC dan CGC $(X)$ berpengaruh langsung terhadap NP(Y) atau sering disebut direct effect, Hubungan $X$ dan $Y$ sering disebut total effect (Pengaruh Total) dengan nilai koefisien total P. Berdasarkan gambar 2 (model jalur stuktur 1) dapat ditulis persamaan regresi sebagai berikut:

$\mathrm{NP}=\mathrm{P}^{*} \mathrm{IC}+\mathrm{P}^{\star} \mathrm{GCG}+\varepsilon$

Gambar 3, menunjukkan pengaruh langsung antara profitabilitas dengan nilai perusahaan .

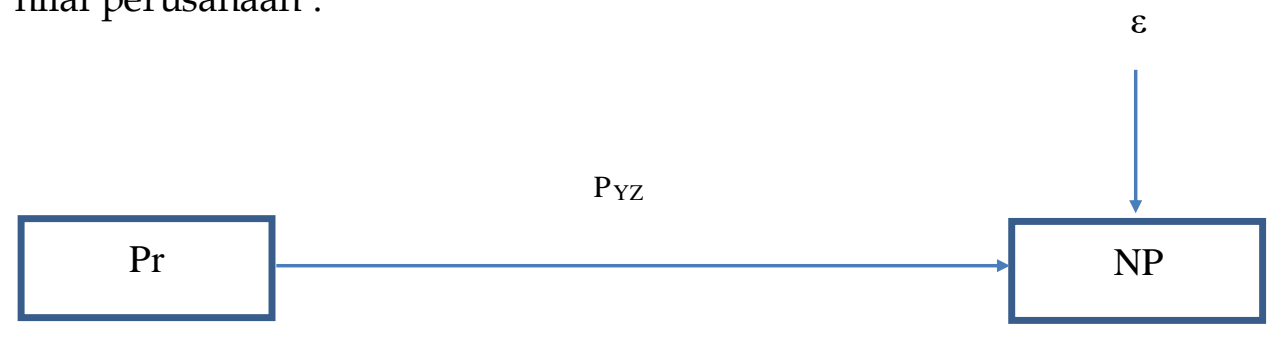

\section{Gambar 3. Model Jalur Struktur 2}

Sumber: Data Penelitian, 2019

Pengaruh langsung antara profitabilitas dengan nilai perusahaan dengan koefisien $\mathrm{P}$, dapat ditulis dengan persamaan regresi sebagai berikut : $\mathrm{NP}=\mathrm{P} * \mathrm{Pr}+\varepsilon$.

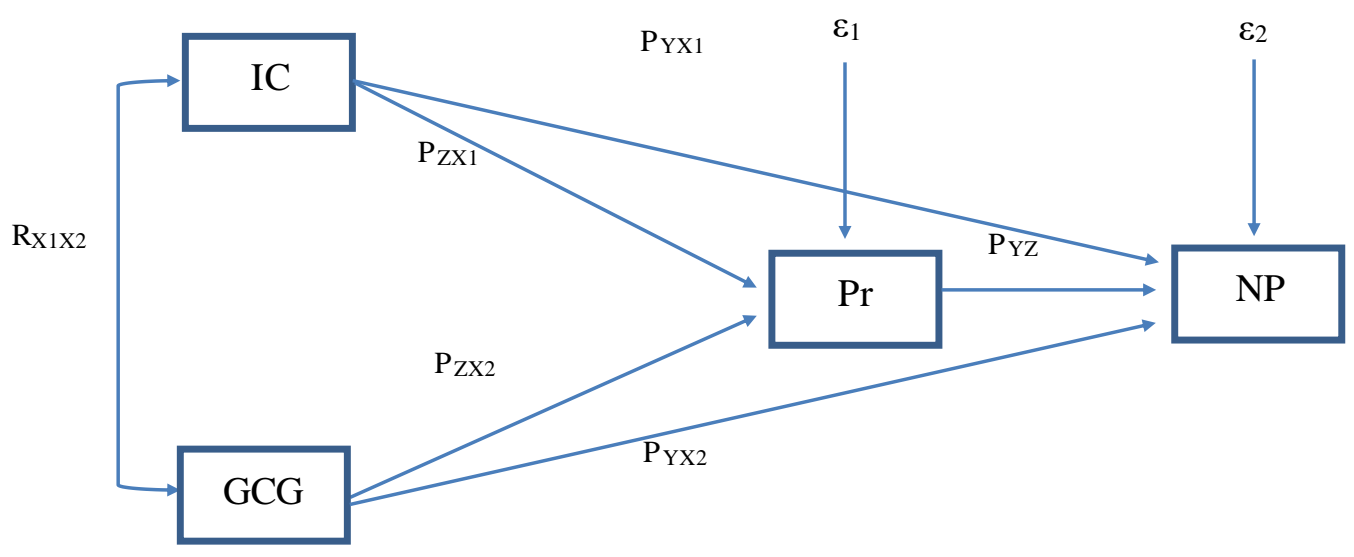

Sumber: Data Penelitian, 2019

Gambar 4. Model Jalur Struktur 3

Gambar 4, menunjukan pengaruh IC dan GCG terhadap NP melalui Pr menggambarkan bentuk mediasi sederhana yaitu pengaruh tidak langsung IC dan GCG $(X)$ terhadap NP $(Y)$, melalui Pr sebagai variabel mediator. Hubungan sederhana antara $X$ dan $Y$, lewat $M$ sebagai variabel mediator. Dari gambar 4, dapat ditulis persamaan regresi sebagai berikut $\mathrm{NP}=\mathrm{a}+\mathrm{P}^{1} \mathrm{IC}+\mathrm{P}^{1} \mathrm{GCG}+\mathrm{Pr}$

Variabel Pr disebut mediator atau intervening jika persamaan (1) X secara signifikan mempengaruhi $Y$ atau $\mathrm{c} \neq 0$ ),

\section{HASIL DAN PEMBAHASAN}

Hasil uji Kolmogorov-Smirnov Z mengindikasikan nilai $p$ (Asymp. Sig.) sebesar 0,269 atau ebih dari di atas 0,05, sehingga dapat disimpulkan bahwa nilai residual regresi memenuhi asumsi normalitas. Dapat dilihat pada Tabel 1. 
Tabel 1. Hasil Uji Normalitas Residual Regresi (Uji Kolmogorov-Smirnov Z)

\begin{tabular}{lll}
\hline & & Unstandardized Residual \\
\hline $\mathrm{N}$ & Mean & 102 \\
Normal Parametersa,b & Std. Deviation & $0 \mathrm{E}-7$ \\
& Absolute & 1.55483488 \\
Most Extreme Differences & Positive & .099 \\
& Negative & -.099 \\
Kolmogorov-Smirnov Z & & 1.001 \\
Asymp. Sig. (2-tailed) & & .269 \\
\hline
\end{tabular}

Sumber: Data Penelitian, 2020

Berdasarkan Tabel 2, diketahui bahwa masing-masing variable independen memiliki nilai VIF kurang 10 atau nilai Tolerance di atas 0,10. Sehingga dapat disimpulkan bahwa antar variable independen dalam penelitian tidak saling berkorelasi kuat. Dengan kata lain, model jalur yang dihasilkan tidak mengandung masalah multikolinearitas.

Tabel 2. Hasil Uji Multikolinearitas (Nilai Tolerance dan VIF)

\begin{tabular}{llll}
\hline Model & \multicolumn{2}{c}{ Collinearity Statistics } \\
\cline { 3 - 4 } & & Tolerance & VIF \\
\hline \multirow{2}{*}{1} & (Constant) & .999 & 1.001 \\
& IC & .999 & 1.001 \\
\hline
\end{tabular}

Sumber: Data Penelitian, 2020

Gambar 5, menunjukkan bahwa titik-titik scatterplot menyebar di atas di atas dan di bawah sumbu nol. Hal ini mengindikasikan bahwa model jalur yang dihasilkan tidak mengandung masalah heteroskedastisitas.

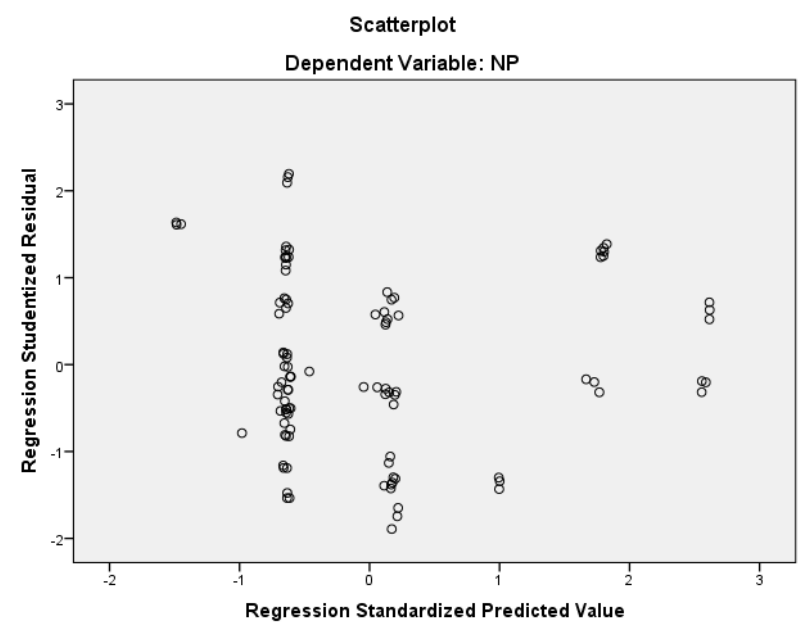

Gambar 5. Grafik Scatterplot untuk Uji Heteroskedastisitas

Sumber: Data Penelitian, 2020

Bobot pengaruh variabel intellectulal capital terhadap nilai perusahaan adalah sebesar -0,043. Hasil uji t menunjukkan nilai $p$ (sig.) sebesar 0,635 atau di atas 0,05, sehingga keputusan yang diambil adalah menerima Ho. Artinya variabel intellectual capital tidak berpengaruh signifikan terhadap variabel nilai perusahaan. Dengan kata lain, koefisien jalur variabel intellectulal capital terhadap 
nilai perusahaan tidak signifikan. Nilai koefisien jalur struktur dapat dilihat pada Tabel 3, berikut.

Tabel 3. Nilai Koefisien Jalur untuk Model Jalur Struktur 1

\begin{tabular}{lllllll}
\hline \multirow{2}{*}{ Model } & \multicolumn{2}{l}{ Unstandardized Coefficients } & $\begin{array}{l}\text { Standardized } \\
\text { Coefficients }\end{array}$ & T & \multirow{2}{*}{ Sig. } \\
\cline { 2 - 5 } & & B & Std. Error & Beta & \\
\hline \multirow{2}{*}{1} & (Constant) & 15.274 & .510 & & 29.928 & .000 \\
& IC & $-4.706 \mathrm{E}-007$ & .000 & -.043 & -.476 & .635 \\
& GCG & .591 & .127 & .424 & 4.652 & .000 \\
\hline
\end{tabular}

a. Dependent Variable: NP

Sumber: Data Penelitian, 2020

Bobot pengaruh variabel good corporate governance terhadap nilai perusahaan adalah sebesar -0,424. Hasil uji t menunjukkan nilai $p$ (sig.) sebesar 0,000 atau kurang dari 0,05, sehingga keputusan yang diambil adalah menerima Ha. Artinya variabel good corporate governance berpengaruh signifikan terhadap variabel nilai perusahaan. Dengan kata lain, koefisien jalur variabel good corporate governance terhadap nilai perusahaan signifikan.

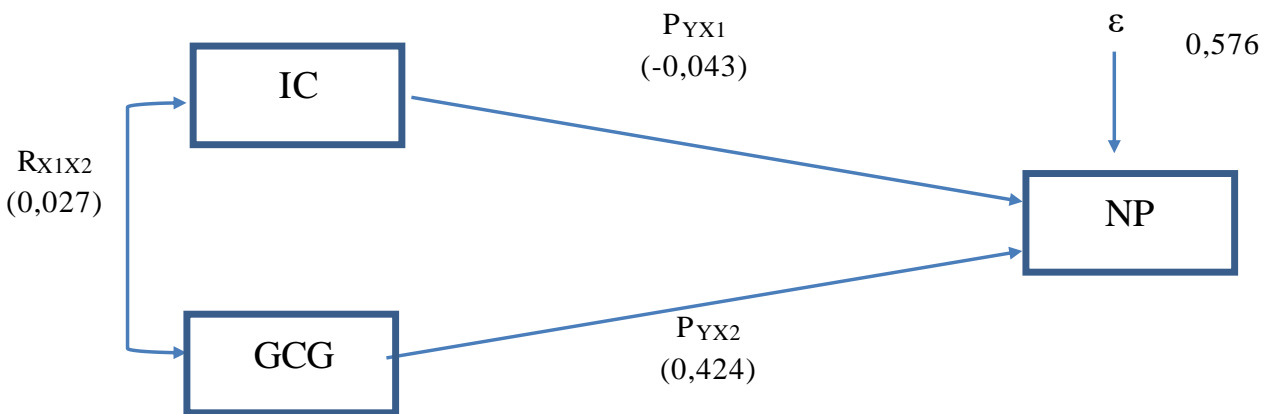

Sumber: Data Penelitian, 2020

Gambar 6. Hasil Analisis Jalur Struktur 1

Hal ini sejalan dengan penelitian yang dilakukan Rajannoor et al., (2014), Diarto et al., (2016) mengemukakan bahwa perusahaan dengan governance yang baik akan memiliki kinerja keuangan yang lebih efisien dan Corporate Governance merupakan pedoman bagi manajer untuk mengelola perusahaan secara best practice. Manajer bekerja secara efektif dan efisien sehingga dapat menurunkan biaya modal dan mampu meminimalkan risiko. Hal ini dapat terlihat pada harapan bahwa kas masa depan yang tinggi sehingga profitabilitas yang diharapkan juga akan semakin meningkat.

Tabel 4. Nilai Koefisien Jalur untuk Model Jalur Struktur 2

\begin{tabular}{|c|c|c|c|c|c|c|}
\hline \multirow[t]{2}{*}{ Model } & & \multicolumn{2}{|c|}{ Unstandardized Coefficients } & $\begin{array}{l}\text { Standardized } \\
\text { Coefficients }\end{array}$ & \multirow[t]{2}{*}{$\mathrm{T}$} & \multirow[t]{2}{*}{ Sig. } \\
\hline & & $\bar{B}$ & Std. Error & Beta & & \\
\hline 1 & (Constant) & 17.448 & .352 & & 49.499 & .000 \\
\hline 1 & $\operatorname{Pr}$ & .124 & .538 & .023 & .230 & .818 \\
\hline
\end{tabular}

a. Dependent Variable: NP

Sumber: Data Penelitian, 2020

Bobot pengaruh variabel kinerja keuangan terhadap nilai perusahaan adalah sebesar 0,023 . Hasil uji $\mathrm{t}$ menunjukkan nilai $p$ (sig.) sebesar 0,818 atau lebih dari 0,05, sehingga keputusan yang diambil adalah menerima Ho. Artinya variabel Profitabilitas berpengaruh signifikan terhadap variabel nilai perusahaan. 
Dengan kata lain, koefisien jalur variabel kinerja keuangan terhadap nilai perusahaan signifikan. Hal ini sejalan hasil dengan penelitian yang dilakukan Rajannoor et al., (2014). Para stakeholder lebih menyenangi perusahaan yang bisa menciptakan nilai bagi kepentingannya.

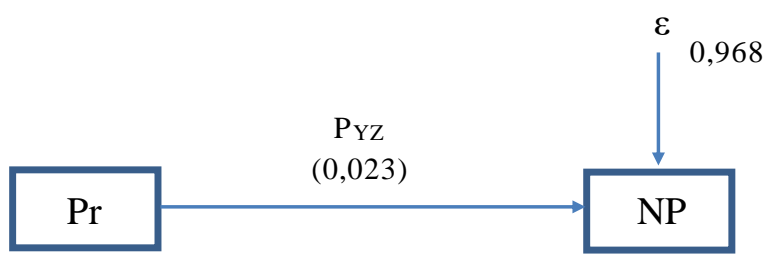

Sumber: Data Penelitian, 2020

Gambar 7. Hasil Analisis Jalur Struktur 2

Jika stakeholdernya calon investor maka kepentingannya terhadap perusahaan adalah perusahaan kinerjanya baik sehingga perusahaan laba dan investor juga mendapat keuntungan dari modal yang ditanamkan di perusahaan tersebut. Sehingga perusahaan yang kinerjanya baik maka akan mampu memenuhi kepentingan stakeholder sehingga sahamnya banyak diminati dan nilai perusahaan menjadi naik.

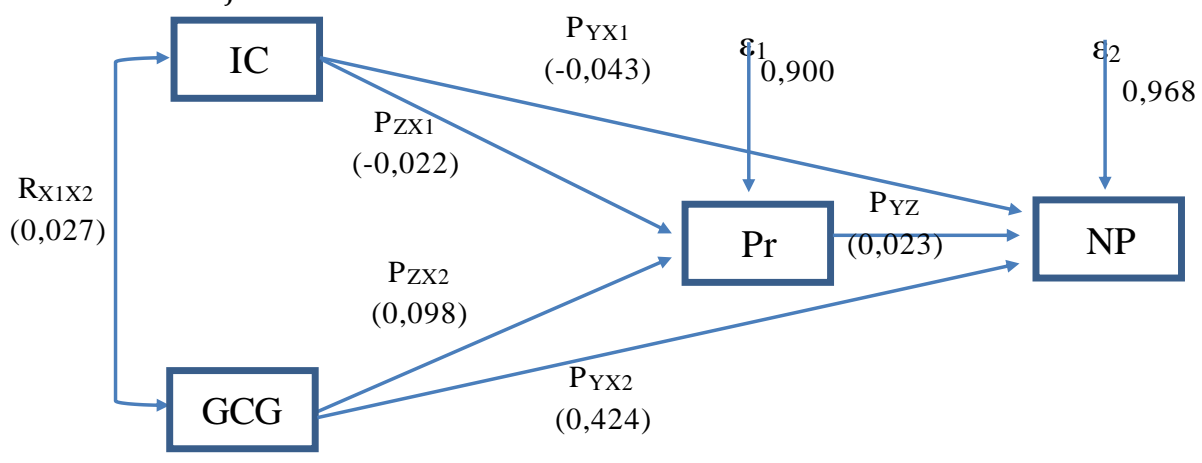

Gambar 8. Hasil Analisis Jalur Struktur 3

Sumber: Data Penelitian, 2020

Pengaruh Intellectual Capital terhadap Nilai Perusahaan melalui Mediasi Profitabilitas (ROE) yaitu ada 2 Pengaruh langsung (direct effect) dan Pengaruh tidak langsung (indirect effect). Pengaruh langsung (direct effect) terdapat Pengaruh intellectual capital terhadap nilai perusahaan (koefisien $a$ ) IC $\rightarrow$ NP : 0,043 (sea: 0,000). Pengaruh intellectual capital terhadap Profitabilitas (ROE) (koefisien $b$ ) IC $\rightarrow$ Pr : -0,022 (seb: 0,000) dan Pengaruh Profitabilitas (ROE) terhadap nilai perusahaan (koefisien $c^{\prime}$ ) Pr $\rightarrow$ NP : 0,023. Sedangkan tidak langsung (indirect effect). Pengaruh tidak langsung (indirect effect) $\left(a^{*} b\right)$ IC $\rightarrow \operatorname{Pr}$ $\rightarrow$ NP : $-0,043^{*}-0,022=0,001$ dan Pengaruh Total (total effect) $(a+b)-0,043+0,001$ $=-0,042$.

Berdasarkan perhitungan, diketahui bahwa bobot mediasi atau pengaruh tidak langsung intellectual capital terhadap nilai perusahaaan melalui kinerja keuangan adalah sebesar 0,001. Pengujian apakah bobot mediasi atau bobot pengaruh tidak langsung signifikan atau tidak dilakukan melalui formula Sobel yang diajukan oleh Baron and Kenny. Hasil uji Sobel menunjukkan nilai Zhitung sebesar 0,474 atau lebih kecil dibandingkan nilai $Z_{\alpha}$ sebesar 1,96. Karena 
itu dapat disimpulkan bobot pengaruh tidak langsung intellectual capital terhadap nilai perusahaan adalah tidak signifikan. Dengan kata lain, bahwa kinerja keuangan tidak mampu memediasi pengaruh intellectual capital terhadap nilai perusahaan.

Perhitungan pengaruh good corporate governance terhadap Nilai Perusahaan melalui Mediasi Profitabilitas (ROE) terdapat perhitungan langsung dan tidak langdung. Pengaruh langsung (direct effect) terdapat 3 hal yang dianalisi yaitu, Pengaruh intellectual capital terhadap nilai perusahaan (koefisien a) GCG $\rightarrow$ NP : 0,424 (sea: 0,127). Pengaruh intellectual capital terhadap Profitabilitas (ROE) (koefisien b), GCG $\rightarrow$ Pr : 0,098 (seb: 0,026). Pengaruh Profitabilitas (ROE) terhadap nilai perusahaan (koefisien $c^{\prime}$ ), $\operatorname{Pr} \rightarrow$ NP : 0,023. Sedangkan Pengaruh tidak langsung (indirect effect) ( $a^{*} b$ ) GCG $\rightarrow \operatorname{Pr} \rightarrow$ NP : 0,424 * 0,098 = 0,522 dan Pengaruh Total (total effect) $(a+b)$ 0,424 +0,522 = 0,946.

Berdasarkan perhitungan tersebut diketahui bahwa bobot mediasi atau pengaruh tidak langsung good corporate governance terhadap nilai perusahaaan melalui Profitabilitas adalah sebesar 0,001. Pengujian apakah bobot mediasi atau bobot pengaruh tidak langsung signifikan atau tidak dilakukan melalui formula Sobel yang diajukan oleh Baron and Kenny. Hasil uji Sobel menunjukkan nilai Zhitung sebesar 0,957 atau lebih kecil dibandingkan nilai $Z_{\alpha}$ sebesar 1,96 . Karena itu dapat disimpulkan bobot pengaruh tidak langsung good corporate governance terhadap nilai perusahaan adalah tidak signifikan. Dengan kata lain, bahwa Profitabilitas (ROE) tidak mampu memediasi pengaruh good corporate governance terhadap nilai perusahaan. Hal ini menunjukkan bahwa good corporate governance berpengaruh langsung terhadap nilai perusahaan tanpa melalui mediator profitabilitas, dengan kata lain dampak dari penerapan good corporate governance dapat dirasakan dalam waktu jangka panjang.

Intellectual capital tidak berpengaruh signifikan terhadap nilai perusahaan subsector perbankan di BEI tahun 2016-2018. Hasil penelitian ini sejalan dengan penelitian yang dilakukan Hanum et al., (2011), hal ini dikarenakan masih banyak perusahaan yang tidak memperhatikan intellectual capial pada perusahaannya, perusahaan lebih cendrung memperhatikan asset berwujud dan mengabaikan pengungkapan intellectual capitalnya. Good corporate governance dan Profitabilitas (ROE) berpengaruh signifikan terhadap nilai perusahaan subsector perbankan di BEI tahun 2016-2018. Penelitian ini sejalan dengan hasil penelitian yang dilakukan oleh Telepta (2011) dan Ogolmagai (2013) hasil penelitian ini merekomendasikan kepada perusahaan agar nilai perusahaan tetap baik, perusahaan perlu memperhatikan kedua aspek tersebut.. Profitabilitas tidak mampu memediasi hubungan intellectual capital terhadap nilai perusahaan subsector perbankan di BEI tahun 2016-2018, hal ini tidak sejalan dengan penelitian yang dilakukan Sunarsih \& Mendra, (2012) dan Sudibya \& Restuti, (2014) yang menemukan bahwa profitabilitas mampu memediasi hubungan antara intellectual capital dengan nilai perusahaan. Kinerja keuangan tidak memediasi pengaruh good corporate governance terhadap nilai perusahaan subsector perbankan di BEI tahun 2016-2018, hasil penelitian ini bertentangan dengan penelitian Dianawati \& Fuadati, (2016). 


\section{SIMPULAN}

Hal ini menunjukkan bahwa good corporate governance berpengaruh langsung terhadap nilai perusahaan tanpa melalui mediator profitabilitas, dengan kata lain dampak dari penerapan good corporate governance dapat dirasakan dalam waktu jangka panjang.Keterbatasan dalam penelitian ini adalah bahwa penelitian ini hanya menggunakan satu indicator saja untuk mengukur variable, untuk penelitian selanjutnya bias menambah proksi/ indicator untuk pengukuran masing-masing variable. Selanjutnya objek penelitian perusahaan yang digunakan terbatas pada perusahaan perbankkan saja sehingga hasil penelitian belum begitu terlihat jika diaplikasikan pada perusahaan lain, sehingga penelitian berikutnya dilakukan pada perusahaan sector lain.

\section{REFERENSI}

Ahriati, D., Basuki, P., \& Widiastuty, E. (2015). Analisis Pengaruh Sistem Pengendalian Internal, Asimetri Informasi, Perilaku Tidak Etis Dan Kesesuaian Kompensasi Terhadap Kecenderungan Kecurangan Akuntansi Pada Pemerintah Daerah Kabupaten Lombok Timur. Jurnal InFestasi.

Bontis, N., Janošević, S., \& Dženopoljac, V. (2015). Intellectual capital in serbia's hotel industry. International Journal of Contemporary Hospitality Management. https://doi.org/10.1108/IJCHM-12-2013-0541

Dianawati, C. P., \& Fuadati, S. R. (2016). Pengaruh CSR Dan GCG Terhadap Nilai Perusahaan: Profitabilitas Sebagai Variabel Intervening. Jurnal Ilmu Dan Riset Manajemen.

Diarto, Ade Putri dan Siti Aisjah. 2016. Analisis Tingkat Kesehatan Bank dengan Menggunakan Metode RGEC (Risk Profile, GCG, Earning, Capital): Studi pada PT. BRI (persero) Tbk periode 2011-2014. Fakultas Ekonomi dan Bisnis. Universitas Brawijaya Malang.

Dženopoljac, V., Janoševic, S., \& Bontis, N. (2016). Intellectual capital and financial performance in the Serbian ICT industry. Journal of Intellectual Capital. https://doi.org/10.1108/JIC-07-2015-0068

Earnest, Dewi Fariha and Saudah Sofian. 2013. The Mediating Role of Corporate Governance on Intellectual Capital and Corporate Performance. Journal of Economics, Business and Management, Vol. 1, No. 4, November.

Fatimah, Malavia, mardani ronny, \& Budi, W. (2017). Pengaruh Good Corporate Governance Terhadap Nilai Perusahaan Dengan Kinerja Keuangan Sebagai Variabel Intervening. E-Jumal Riset Manajemen Prodi Manajemen.

Farida, Anisatul. 2016. Pengaruh Struktur Corporate Governance dan Intellectual Capital terhadap Kinerja Perusahaan yang terdaftar di Jakarta Islamic Index (JII) Periode 2011-2014. Fakultas Syari'ah dan Hukum, Universitas Islam Negeri Sunan Kalijaga Yogyakarta.

Hadiwijaya, Rendi Cahyono dan Abdul Rohman. (2013) "pengaruh intellectual capital terhadap nilai perusahaan dengan kinerja keuangan sebagai variabel intervening diponegoro journal of accounting Volume 2, Nomor 3, Tahun 2013, Halaman 1-7 http://ejournals1.undip.ac.id/index.php/accountingISSN (Online): 2337-3806

Hanum, M., Kamal, M., Mat, R. C., Rahim, N. A., Husin, N., \& Ismail, I. (2012). Intellectual Capital And Firm Performance Of Commercial Banks In 
Malaysia. Asian Economic and Financial Review Journal

Harryani, Sri, Bagus Nurcahyo, Renny Nur'aini. 2013. Impact of Intellectual Capital on the Firm's Market Value: The Mediation Role of Financial Performance (Empirical Study From The Indonesian Banking Companies since 2007-2011). 10th Ubaya International Annual Symposium on Management

Hashim, Maryam Jameelah, Idris Osmanb, Syed Musa Alhabshic. 2015. Effect of Intellectual Capital on Organizational Performance. 2nd Global Conference on Business and Social Science-2015, GCBSS-2015, 17-18 September 2015, Bali, Indonesia

Rajannoor, Muhammad dan Aulia Fuad Rahman. 2014. Analisis Pengaruh Penerapan Good Corporate Governance terhadap manajemen Laba pada perusahaan BUMN (Studi Pada Perusahaan BUMN yang Terdaftar di Bursa Efek Indonesia 2012-2014). Universitas Diponegoro Semarang.

Jayanti, L. D., \& Binastuti, S. (2017). Pengaruh Intellectual Capital Terhadap Nilai

Perusahaan Dengan Kinerja Keuangan Sebagai Variabel Intervening. Jurnal Ekonomi Bisnis.

Khanqah, V. T., Khosroshahi, M. A., \& Ebrati, M. R. (2012). An Investigation of the Association between Working Capital Management and Corporate Performance. Int. Journal of Management and Business Research.

Langeroodi, Iman Salemi. 2014. The Effect of the Knowledge Management and Intellectual Capital on Organizational Performance in State Banks of RASHT. Indian Journal of Fundamental and Applied Life Sciences ISSN: 22316345 (Online). An Open Access, Online International Journal Available at http:// http://www.cibtech.org/sp.ed/jls/2014/01/jls.htm. 2014 Vol. 4 (S1) April-June, pp. 1393-1404/Langeroodi

Lisdayanti, Agustya dan Suhendra. 2016. The Effect of Intellectual Capital on Firm Value Through Firm Performance (Empirical Study on Manufacturing Companies listed on the Indonesia Stock Exchange). FE-Universitas Gunadarma Jakarta.

Mojtahedi, Payam and Eskandar Jafari. 2013. Investigating the impact of Intellectual Capital on Market Value Added Evidence from Malaysian firms. Technical Journal of Engineering and Applied Sciences. Available online at www.tjeas.com C2013 TJEAS Journal-2013-3-20/2696-2701 ISSN 20510853 @2013 TJEAS

Natalia Ogolmagai. 2013. Leverage Pengaruhnya Terhadap Nilai Perusahaan pada Industry Manufaktur yang Go Public di Indonesia. Jurnal EMBA Vol.1 No.3 Juni 2013, Hal 81-89. ISSN: 2303-1174.

Nida, Shofwatun. 2015. Pengaruh Intellectual Capital dan Good Corporate Governance terhadap Profitabilitas Bank Umum Syariah Periode 2010-2013. Konsentrasi Perbankan Syariah, Program Studi Muamalat, Fakultas Syariah dan Hukum, Universitas Islam Negeri (UIN) Syarif Hidayatullah Jakarta.

Nuryaman. 2015. The Influence of Intellectual Capital on The Firm's Value with The Financial Performance as Intervening Variable. 2nd Global Conference on Business and Social Science-2015, GCBSS-2015, 17-18 September 2015, Bali, Indonesia 
Sawarjuwono, T., \& Kadir, A. P. (2003). Intellectual Capital : Perlakuan, Pengukuran dan Pelaporan. Jurnal Akuntansi Dan Keuangan.

Seyed Alireza Mosavi. (2012). A study of relations between intellectual capital components, market value and finance performance. African Journal of Business Management. https://doi.org/10.5897/ajbm11.1466

Sudibya, diva cicilya arum, \& Restuti, M. M. D. (2014). Pengaruh Modal Intelektual Terhadap Nilai Perusahaan Dengan Kinerja Keuangan Sebagai Variable Intervening. Journal Manajemen Dan Bisnis.

Sunarsih, N. M., \& Mendra, N. P. Y. (2012). Pengaruh Modal Intelektual Terhadap Nilai Perusahaan Dengan Kinerja Keuangan Sebagai Variabel Intervening Pada Perusahaan Yang Terdaftar Di Bursa Efek Indonesia. SNA $X V$ Banjarmasin.

Wany, E. (2010). Pengaruh Intellectual Capital Terhadap Produktivitas, Profitabilitas, Nilai Pasar Pada Perusahaan Manufaktur Di Bursa Efek Indonesia. AKRUAL: Jurnal Akuntansi. https://doi.org/10.26740/jaj.v2n1.p20-42

Widigdo, Idie. 2013. Effect of Corporate Social Performance, Intellectual Capital, Ownership Structure, and Corporate Governance on Corporate Performance and Firm Value (Studies on Comapnies Listed in the Sri-Kehati Index). International Journal of Business, Economics and Law, Vol. 2, Issue 1 (June) 2013 ISSN 2289-1552

www.idx.co.id. 